\title{
Interpretation of Social Value, Protection and Utilization of Red Revolutionary Culture Resources in Sichuan
}

\author{
Chunqiu Luo \\ Panzhihua University, Panzhihua 617000, China \\ E-mail:rexrex1985@126.com
}

Keywords: Sichuan; red revolutionary culture resources; social value; protection and utilization

\begin{abstract}
As the most important cultural heritage in our country, red revolutionary culture resources no only enriched the connotation of tourism resources in China, but also played a positive role in promoting the development of tourism. Sichuan Province has rich red tourism resources, and these resources play an irreplaceable role in creating an international boutique tourist area in China. Red revolutionary culture resources have high social value, which is of great significance for the progress and development of society. This paper mainly analyzes the social value of Sichuan red resources, and then expounds the protection and utilization of them.
\end{abstract}

\section{Introduction.}

Sichuan Province, as the hometown of red revolutionary culture resources in China, possesses tremendous resources, which cover the political, economic and cultural contents of each period. These rich cultures play an important role in promoting the development and utilization of red tourism resources in Sichuan. In recent years, Sichuan's red revolutionary culture resources are facing severe challenges. We should strengthen the protection of them in Sichuan Province, and carry out a comprehensive analysis of the typical culture resources of red revolutionary in Sichuan area, also formulate relevant policies to protect the material and cultural heritage of the regions, together with combining the actual development of the Sichuan region to develop and utilize the red revolutionary culture resources rationally, finally promote the further development of red culture tourism in Sichuan area.

\section{The Status Quo of the Protection of Red Revolutionary Culture Resources in Sichuan}

\subsection{Lacking of protection in red cultural relics in Sichuan}

At present, although the tourism resources of red revolutionary culture in Sichuan are relatively rich, most of the red tourism areas are located in areas with relatively weak economic foundation. The protection of red revolutionary culture resources can not adapt to the actual needs of development, and many red cultural relics can not be protected reasonably, lacking of investment in its protection, also in the process of daily maintenance, because of the shortage of a large amount of capital 
investment, many sites can not be effectively protected.

\subsection{Lacking of propaganda on red cultural relics}

The Sichuan area is short of the publicity of red revolutionary culture resources, and the importance of the red culture is not enough too, what is, it has not been promoted in time. This hindered the development and dissemination of red culture to a great extent. In addition, the research work of the relevant departments on red culture is not in place, and the red culture can not be further excavated. In the course of the actual tourism development, we only focus on the publicity of landscape and scenic spots, and the contents of red culture, such as historical events, figures, backgrounds and other aspects of the introduction, resulting in the shortage of a certain sense of red culture to the part of the tourists.

\section{The Social Value of Red Revolutionary Culture Resources in Sichuan}

\subsection{Political value}

In the social value of Sichuan's red revolutionary culture resources, its political value is the first place among all. To some extent, red culture helps to strengthen the party's governing capability and improves the ruling of the Communist Party of China, which is closely related to the ruling theory as well as the quality of the ruling team. The promotion of the ruling theory of the Communist Party is closely related to the red culture, which is formed on the basis of the inheritance of the red culture. In addition, we use red revolutionary culture resources to educate and train party organizations at all levels in China. The idea of promoting party organization, "establish the party for the public and for the people to govern the people" , is to enhance the national cohesion of the Sichuan region, and improve the consciousness of national unity, also promote the social harmony and stability of the region. In a word, red culture is the foundation of the ruling theory of the Communist Party of China and is of great significance to the improvement of the Party's leadership.

\subsection{Educational value}

At present, Sichuan's red culture, as an important part of socialist culture, has great educational value. It embodied in the red culture what mainly reflected in the following aspects. Firstly, the red culture has a certain educational inheritance in the course of the whole education. Sichuan is a region with rich red cultural resources in China, with plentiful resources in the actual process of inheritance, is a kind of political and moral culture and the spread and development of culture. The development of the new culture needs to be built on the basis of the transformation and innovation of the old culture, and properly learn and obsolete the old and decadent ideas, also actively develop the advanced socialist culture. Secondly, the red culture has certain creative function. At present, the red culture education has been greatly permeated in every field of our society, especially in the social culture. It not only enriches the contents of culture, but also promotes the good development of culture, as well as strengthens the blending of national culture and social culture, finally provides a good foundation for the construction of socialist culture with Chinese characteristics.

\section{The Exploitation and Utilization of Red Revolutionary Culture Resources in Sichuan}

\subsection{Strengthening the protection of red revolutionary culture resources}

In the process of development and utilization of red resources in Sichuan, it is necessary to 
strengthen the protection of red resources and improve the management level of red resources. And according to the actual situation in Sichuan, strengthen and improve the relevant protection provisions, then establish and improve the protection mechanism of red resources. The local governments should increase the investment in the development and utilization of red revolutionary culture resources, also repair the abandoned buildings or statues, as well as protecting the relics of the Red Army, together with making strict management standards and norms to put them into practice. In addition, the Red Army slogans scattered in various regions are collected and protected in a unified way, and the records are recorded to ensure the effective protection of the remains of the Red Army during the period.

\subsection{Giving full play to the advantages of red revolutionary culture resources and promoting the development of red tourism in Sichuan}

In the process of speeding up the development of tourism in Sichuan, we should make full use of the advantages of red revolutionary culture resources, and actively develop the red cultural tourism project also establish the road of the development of the red culture tourism. First of all, the Sichuan area should make a comprehensive investigation of the existing red relics, and bring them into the scope of the archives management, then record the red cultural relics together, also integrate them in an all-round way and establish the red tourism base. For example, the cultural preservation sites involved in the Red Army's Long March, the characteristic town of Hongyuan County, and the cultural walls of the Red Army were integrated in an all-round way. These red revolutionary culture resources will be turned into red products.

\subsection{The combination of revolutionary traditional education and tourism development}

In the course of developing the tourism development route of Sichuan, it is necessary to combine the revolutionary traditional culture with the tourism development route, and carry forward the traditional education of the Red Army also bring the effect of the tourism industry into full play as well as promoting the rapid economic development of the Sichuan region. For example, the route, cultural relics and relics of the Red Army during the long march of the Red Army are the key development targets, we need to repair the damaged relics, and integrate the characteristic culture of the Sichuan region, also enrich the contents of the red culture. In addition, we should make full use of the local resources, and actively open up the special lines such as "the long march of the Red Army, the trace of the Red Army, the snow, and snow mountain, the crossing of the Jinsha River". What's more, we also need to play the role of national customs in the Qiang District of Sichuan area, and integrate it into the tourism development projects, for they not only highlight the ethnic characteristics of the region, but also enrich the tourism contents, which add the ethnic style to the development of the red culture tourism in Sichuan.

\subsection{Developing red tourism in combination with major commemorative days}

In the process of developing red cultural resources, Sichuan needs to collect past major commemorative days, festivals and so on. Tourism development projects are combined with these major festivals to actively carry out red tourism activities. Through the development of red cultural tourism activities, they not only help to enrich the contents of tourism activities, but also can carry forward the red culture and spread to more and more people to help tourists understand the red culture at the same time. In addition, through the development of red culture tourism activities, visitors can greatly increase their own experience on the characteristics of Sichuan red culture tourism products. 


\section{Conclusion}

To sum up, Sichuan red revolutionary culture resources as an important resource at present, is an important part of socialist culture. Although Sichuan has a wide variety, large quantity and rich contents of red resources, it has not been reasonably developed and used, which has caused a waste of red revolutionary culture resources. Therefore, the relevant government departments of the Sichuan region should make a comprehensive analysis of the existing problems of the red culture at present, based on the actual situation in the Sichuan region, and integrate the existing red revolutionary culture resources, and give full play to the advantages of the red revolutionary culture resources. Combining them with the local conditions, social conditions and Humanities in Sichuan intensify the publicity of the red revolutionary culture resources to promote the Sichuan region.

\section{Acknowledgments}

Project of 2018 Sichuan Wangyoumu Research Center "Research on the development, utilization and protection of Sichuan red cultural resources", Project Number: SCWYM2018YB13.

\section{References}

[1] Chen Gang. A Research on Red Culture Resources in Ideological and Political Theory Course--Taking Sichuan University of Arts and Sciences as an Example[J].Journal of Sichuan University of Arts and Sciences, 2018,28(04): 140-145.

[2] Feng Wei, Bai Lang. A Research on the Path of "Culture + Industry" Development in Bazhong Area of Sichuan [J].Rural Economy and Science and Technology, 2017, 28 (21): 182-184.

[3] Feng Wei, Wu Xiulin.Based on the path of integration and docking of red cultural industry and green industry in Bazhong area of Sichuan [J].Economic Forum, 2017 (04): 60-62.

[4] Eu Tingyu.The Application of Sichuan Red Resources in Cultivating Young People's Socialist Values [J].Decision-making and Information, 2016 (09): 78-85.

[5] Liu Jianping, Wang Hongshu. Contemporary Value and Development Thoughts of Red Culture Resources in Sichuan Tibetan Area--Taking Ganzi Prefecture as an Example[J].Theoretical Observation, 2016 (01): 105-109. 